\title{
Pengobatan suportif pyometra terbuka pada kucing Mainecoon $\uparrow$
}

\author{
Andre Giovanni ${ }^{1,3, *}$, Ajeng Aeka Nurmaningdyah ${ }^{2,}$, Muhamad Arfan Lesmana ${ }^{2, \#}$ \\ ${ }^{1}$ Program Profesi Dokter Hewan, Fakultas Kedokteran Hewan, Universitas Brawijaya, Malang, Indonesia \\ ${ }^{2}$ Departemen Klinik Hewan Pendidikan, Fakultas Kedokteran Hewan, Universitas Brawijaya, Malang, Indonesia \\ ${ }^{3}$ Master Program of Ornamental Fish and Aquatic Animal Health, National Pingtung University Science and \\ Technology, Pingtung, Taiwan
}

\begin{abstract}
ABSTRAK: Pyometra merupakan infeksi pada uterus yang bersifat akut maupun kronis dengan adanya akumulasi cairan pus (nanah) didalam uterus. Pyometra terdiri atas dua jenis yaitu pyometra terbuka dan pyometra tertutup. Tulisan ini melaporkan penanganan kasus pyometra di Klinik Hewan Pendidikan Fakultas Kedokteran Hewan Universitas Brawijaya. Seekor kucing Mainecoon dibawa pemiliknya datang dengan keluhan pada vagina keluar lendir sejak beberapa hari sebelum dibawa ke klinik. Kucing sudah dua kali melahirkan dan belum pernah dilakukan steril (ovariohisterektomi) sebelumnya. Pemeriksaan penunjang yang dilakukan berupa ultrasonografi, radiografi, hematologi, dan kimia darah. Hasil pencitraan ultrasonografi dan radiografi didapati adanya penimbunan cairan di dalam uterus dan dinding uterus tampak terjadi penebalan. Terapi pengobatan suportif menggunakan kombinasi Sanpicillin $\AA$, Cefotaxime $\AA$, Clavamox ${ }^{\circledR}$, Methylgometrin, Entrostop $\AA$, Neurobion white $\AA$,

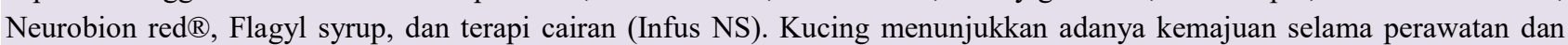
dinyatakan sembuh setelah mendapatkan pengobatan suportif tanpa dilakukan tindakan operasi.
\end{abstract}

\section{Kata kunci:}

kucing, mainecoon, pyometra, terapi suportif

\section{- PENDAHULUAN}

Pyometra merupakan penyakit saluran reproduksi hewan betina dan sering terjadi pada anjing dan kucing. Pyometra merupakan infeksi pada uterus yang dapat bersifat akut maupun kronis oleh infeksi bakteri. Gejala klinis yang tampak yaitu polydipsia, lethargy, distensi abdominal dan pada kasus pyometra terbuka tampak discharge pada vagina (Hagman 2018, McCallin et al. 2018, Smith 2006) Manifestasi klinis dan patologis kasus pyometra dapat terjadi secara lokal ataupun sistemik. Infeksi bakteri pada fase akut ataupun kronis supuratif pada uterus post estrum tampak adanya akumulasi dari eksudat inflamasi di lumen uterus.

Terdapat dua tipe pyometra yang terjadi pada hewan kecil, yaitu tipe terbuka dan tipe tertutup. Kondisi pasien pyometra terbuka akan menunjukkan gejala klinis yaitu keluar cairan pus dari vagina, namun pada kondisi pyometra tertutup tidak ada cairan yang keluar dari vagina. Kasus pyometra tertutup harus segera ditangani karena akan menyebabkan sepsis hingga kematian pasien (Hagman 2018, McCallin et al. 2018, Smith 2006). Tindakan yang dapat dilakukan yaitu pengangkatan uterus atau pengobatan suportif untuk mengurangi gejala klinis yang muncul. Keberhasilan penanganan secara supportif hingga saat ini sulit ditemukan. Tulisan ini melaporkan penanganan kasus pyometra pada kucing melalui tindakan terapi suportif.

\section{- KASUS}

Riwayat: Kucing betina ras mainecoon berusia 2,5 tahun dengan berat badan 4,84 kg dibawa klien ke Klinik Hewan Pendidikan Fakultas Kedokteran Hewan Universitas Brawijaya.

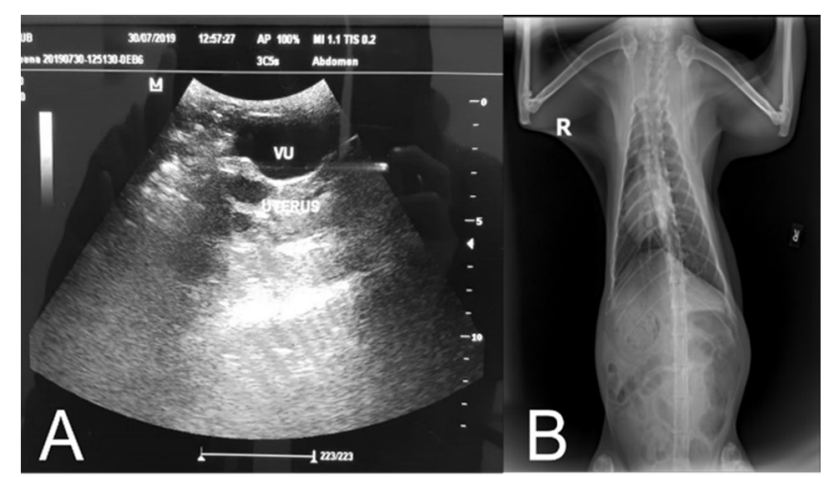

Gambar 1 Citra ultrasonografi (A) dan radiografi (B)

Anamnesis: klien mengeluhan dari vagina kucing keluar lendir sejak beberapa hari sebelum dibawa ke klinik. Kucing sudah 2 kali melahirkan dan belum pernah dilakukan tindakan steril (ovariohisterektomi). Temuan klinis: kucing mengalami diare. Pemeriksaan: Pemeriksaan penunjang yang dilakukan berupa

Received: 07-01-2021 | Revised: 11-02-2021 | Accepted: 15-02-2021

(C) 2021 CC-BY-SA. This is an Open Access article that is distributed under the terms of Creative Commons Attribution ShareAlike 4.0 International License (https://creativecommons.org/licenses/by-sa/4.0/). 
ultrasonografi (USG), X-ray, hematologi, dan kimia darah. Diagnosa: pyometra. Prognosa: fausta. Terapi: rawat inap dengan diberikan pengobatan suportif tanpa dilakukan tindakan bedah. Pengobatan suportif menggunakan Sanpicillin ${ }^{\circledR}(23 \mathrm{mg} / \mathrm{kg} \mathrm{bb})$, Cefotaxime ${ }^{\circledR}(15 \mathrm{mg} / \mathrm{kg} \mathrm{bb})$, Clavamox ${ }^{\circledR}(12,9 \mathrm{mg} / \mathrm{kg} \mathrm{bb})$, Methylgometrine maleat $(0,1$ $\mathrm{mg} / \mathrm{kg} \mathrm{bb})$, Entrostop ${ }^{\circledR}(18 \mathrm{mg} / \mathrm{kg} \mathrm{bb})$, Neurobion white ${ }^{\circledR}$ (50 mg/cat), Neurobion $\operatorname{red}{ }^{\circledR}(50 \mathrm{mg} / \mathrm{cat})$, Flagyl syrup (5 $\mathrm{mg} / \mathrm{kg} \mathrm{bb}$ ), dan terapi cairan (Infus NS).

\section{- HASIL DAN PEMBAHASAN}

Hasil pemeriksaan ultrasonografi menunjukkan terdapat penimbunan cairan pada bagian uterus dan dinding terlihat mengalami penebalan (Gambar 1, S1.1 dan S1.2). Hasil hematologi dan kimia darah disajikan pada informasi pendukung (Tabel S2.1 dan S2.2). Hasil pemeriksaan darah lengkap didapati adanya peningkatan sel darah putih $26 \times 10^{3} / \mu \mathrm{L}$. Selain leukositosis, terjadu peningkatan granulosit $23 \times 10^{3} / \mu$ L. Peningkatan sel darah putih (leukositosis) disebabkan oleh respons fisiologis tubuh terhadap adanya infeksi atau radang akut (Bijanti et al. 2010).

Penurunan kadar hemoglobin menjadi 7,7 g/dL disebabkan oleh anemia. Kadar hemoglobin pada keadaan normal relatif konstan dengan mempertahankan keseimbangan antara pelepasan dan keluarnya eritrosit dari sirkulasi. Ketika kondisi pelepasan eritrosit dalam sirkulasi menurun, atau penghancuran eritrosit meningkat tanpa diimbangi dengan peningkatan produksi dapat mengakibatkan anemia. Penurunan nilai $\mathrm{MCH}$ dan MCHC menunjukkan anemia regeneratif, yang mana sumsum tulang masih dapat membentuk eritrosit didalam tubuh. Anemia regeneratif dapat disebabkan perdarahan atau destruksi eritrosit (Bijanti et al. 2010). Hasil pemeriksaan kimia darah menunjukkan tidak terdapat abnormalitas pada kucing ini (Tabel S2.2).

Tindakan pembedahan tidak dilakukan karena pemilik hanya ingin dilakukan pengobatan suportif. Terapi supportif menggunakan Sanpicillin ${ }^{\circledR}$, Cefotaxime $\AA$, Clavamox ${ }^{\circledR}$, Methylgometrine maleat, Entrostop $\AA$, Neurobion white ${ }^{\circledR}$, Neurobion $\operatorname{red}{ }^{\circledR}$, dan Flagyl syrup. Sanpicillin ${ }^{\circledR}$ mengandung ampicillin yang merupakan antibiotik golongan betalaktam. Antibiotik golongan beta-laktam bekerja mengganggu sintesis dinding sel bakteri (Kemenkes 2011). Cefotaxime ${ }^{\circledR}$ merupakan antibiotik golongan cephalosporin yang bekerja menghambat sintesis peptidoglikan serta mengaktifkan enzim autolisis pada dinding sel bakteri. Clavamox ${ }^{\circledR}$ merupakan antibiotik dengan kombinasi kandungan amoxicillin dan asam clavulanate untuk memperluas spektrum aktivitas (Nurmala et al. 2015) Methylgometrin ${ }^{\circledR}$ umum digunakan untuk penanganan partus atau perdarahan uterus pasca aborsi. Pemberian methylgometrine maleat memiliki kontraiindikasi pada tindakan bedah dengan indikasi preeklamsia dan eklamsia karena dapat memperparah hipertensi (Dewi 2007). Pemberian methylgometrine maleat bertujuan untuk membantu dan mempercepat proses pengeluaran pus dari dalam uterus.
Entrostop ${ }^{\circledR}$ merupakan obat diare yang mengandung attalpugite dan pectin. Zat ini bekerja dengan melapisi selaput lendir usus yang meradang dan menyerap bagian berair sehingga memperbaiki pembentukan feses (Oktaviani 2016). Kucing pada kasus ini diberikan Enterostop ${ }^{\circledR}$ untuk mengobati diare. Flagyl ${ }^{\circledR}$ syrup mengandung metronidazole. Metronidazole menekan aktivitas bakteri kokus, basil gram negatif dan positif anaerob, termasuk berbagai spesies bacteroides pembentuk spora (Brunton 2011). Metronidazole bekerja menghambat sintesis protein pada bakteri (Allerton 2020). Pemberian kombinasi antibiotik termasuk metronidazole diperlukan dalam pengobatan kasus ini karena jumlah pus pada lumen uterus yang banyak. Setelah dilakukan serangkaian pemeriksaan hingga pengobatan selama rawat inap, pasien menunjukkan kemajuan dan dinyatakan sembuh setelah mendapatkan pengobatan suportif tanpa dilakukan tindakan operasi.

\section{SIMPULAN}

Pengobatan supportif menggunakan kombinasi dari beberapa obat dapat digunakan untuk terapi pada kasus pyometra.

\section{• INFORMASI PENDUKUNG}

$\dagger$ Hasil pemeriksaan hematologi dan kimia darah, sonogram, dan dokumentasi kasus tersedia sebagai informasi pendukung.

\section{n INFORMASI PENULIS}

\section{Penulis Korespondensi}

*AG: andregio7796@gmail.com

Program Profesi Dokter Hewan, Fakultas Kedokteran Hewan, Universitas Brawijaya, Malang, Indonesia

\#MAL: arfan_lesmana@ub.ac.id

Departemen Klinik Hewan Pendidikan, Fakultas Kedokteran Hewan, Universitas Brawijaya, Malang, Indonesia

\section{- PUSTAKA ACUAN}

Allerton F. 2020. BSAVA small animal formulation 10th Part A: Canine and feline. British Small Animal Veterinary Association

Bijanti R, Yuliani MGA, Wahjuni RS, Utomo RB. 2010. Buku ajar patologi klinik veteriner. Surabaya: UNAIR Press.

Brunton L, Parker K, Blumenthal D, Buxton I. 2011. Manual Farmakologi dan Terapi. Jakarta: EGC

Dewi NKT. 2007. Evaluasi penggunaan obat pada pasien pasca bedah sesar di Bangsal Bakung Timur Rumah Sakit Sanglah Denpasar Periode Februari 2007. Yogyakarta: Universitas Sanata Dharma.

Hagman R. 2018. Pyometra in small animals. Veterinary Clinics: Small Animal Practice. 48(4): 639-661.

[Kemenkes] Kementrian Kesehatan. 2011. Pedoman umum penggunaan antibiotik. Jakarta: Kementrian Kesehatan RI.

Nurmala, Virgiandhy IGN, Andriani A, Liana DF. 2015. Resistensi dan sensitivitas bakteri terhadap antibiotik di RSU dr. Soedarso Pontianak tahun 2011-2013. eJournal Kedokteran Indonesia. 3(1): 21-28.

Oktaviani L. 2016. Uji antidiare ekstrak rimpang rumput teki (Cyperus rotundus L.) dibandingkan dengan obat attapulgite pada mencit (Mus musculus L.) jantan yang diinduksi Oleum ricini. Bandar Lampung: FMIPA Universitas Lampung.

Smith FO. 2006. Canine pyometra. Theriogenology. 66(3): 610-612. 